\title{
Body size in beef cows and its influence on calf production
}

\section{Tamanho corporal de vacas de corte e sua influência na produção de bezerros}

\author{
Carina Crizel da Vara ${ }^{1}$; Magali Floriano da Silveira ${ }^{2}$; Ricardo Zambarda Vaz ${ }^{3}$; \\ João Restle ${ }^{4}$; Diego Soares Machado ${ }^{5}$; Stefani Macari ${ }^{6}$
}

\begin{abstract}
Highlights:
Light size cows are more productive.

Non-ideal nutritional conditions limit reproductive performance.

Heavier cows produce heavier calves.
\end{abstract}

\begin{abstract}
Cattle farming becomes more intensive when the productive efficiency of the cows is increased, and nutrition is adjusted to the animal biotype. Eighty purebred Charolais and Nellore cows and their crosses between 3 and 7 years of age, were grouped for body weight at calving into Light $(332.6 \mathrm{~kg})$, Moderate $(385.3 \mathrm{~kg})$ and Heavy $(444.6 \mathrm{~kg})$. Cows and their calves were weighed at calving, at 63 days (early weaning) and at 210 days. The estimated milk production of the cows was evaluated by manual milking at 21, 42 and 63 days postpartum. The difference in the weight of the cows at calving was maintained during lactation and at 210 days postpartum. The body size of the cow did not influence milk production. Heavier cows produce heavier calves up to 365 days of age compared to lighter cows. The reproductive performance of the cows is not affected by their weight. The production of kilograms of calf for every 100 kilograms of cow at calving and weaning is higher in Light cows. The production of kilograms of calf adjusted for the pregnancy rate of the cows is higher in Heavy cows. Production efficiency in kilograms of calf per area is lower in Heavy cows.
\end{abstract}

Key words: Efficiency. Frame. Milk production. Weight gain.

\section{Resumo}

\begin{abstract}
A intensificação da pecuária de corte ocorre quando se busca o aumento da eficiência produtiva da vaca, e o ajuste da nutrição ao biótipo animal. Oitenta vacas cruzas Charolês, Nelore e suas cruzas entre 3 e 7 anos, foram agrupadas quanto ao peso corporal ao parto em Leves $(332,6 \mathrm{~kg})$, Moderadas $(385,3$ $\mathrm{kg}$ ) e Pesadas $(444,6 \mathrm{~kg})$. Vacas e os seus bezerros foram pesados ao parto, aos 63 (desmame precoce)
\end{abstract}

\footnotetext{
${ }^{1}$ Discente do Curso de Mestrado do Programa de Pós-Graduação em Zootecnia, Universidade Federal de Pelotas, UFPEL, Pelotas, RS, Brasil. E-mail: carinavara@hotmail.com

2 Prof $^{\mathrm{a}}$ Dr $^{\mathrm{a}}$, Curso de Graduação em Zootecnia, Universidade Tecnológica Federal do Paraná, UTFPR, Dois Vizinhos, PR, Brasil. E-mail: magalisilveira@utfpr.edu.br

3 Prof. Dr., Curso de Graduação em Zootecnia, Universidade Federal de Santa Maria, UFSM, Palmeira das Missões, RS, Brasil. E-mail: rzvaz@terra.com.br

4 Prof. PhD, Programa de Pós-Graduação em Zootecnia, Universidade Federal de Goiás, UFG, Goiânia, GO, Brasil. E-mail: jorestle@terra.com.br

5 Pesquisador, UFSM, Santa Maria, RS, Brasil. E-mail: dsm_zootecnista@hotmail.com

6 Prof. Dr., Programa de Pós-Graduação em Zootecnia, UFPEL, Pelotas, RS, Brasil. E-mail: stefanimacari@yahoo.com.br

* Author for correspondence
} 
e aos 210 dias. A estimativa da produção de leite das vacas foi avaliada com ordenha manual aos 21 , 42 e 63 dias pós-parto. A diferença ao parto no peso das vacas se manteve durante a lactação e aos 210 dias pós-parto. O tamanho corporal das vacas não influenciou a produção de leite. Vacas de maior peso produzem bezerros mais pesadas até os 365 dias de idade quando comparadas às vacas leves. O desempenho reprodutivo das vacas não é afetado pelo peso das vacas. A produção de quilogramas de bezerros para cada 100 quilogramas de vacas ao parto e ao desmame é maior em vacas Leves. A produção de quilogramas de bezerros ajustados para a taxa de prenhez das vacas é maior em vacas Pesadas. A eficiência de produção em quilogramas de bezerros por área é menor para vacas Pesadas.

Palavras-chave: Eficiência. Frame. Ganho de peso. Produção de leite.

\section{Introduction}

For beef farming to become more intensive it is essential to seek greater productive efficiency for the cow within the production system. In Brazil, the herds of livestock suffer from beef cattle have low pregnancy rates and long calving intervals (Silva et al., 2015). This directly compromises the efficiency of the farm, and limits beef production in the country.

Reductions in the interval from birth to the first postpartum oestrus, in addition to other factors, is determined by nutritional management (Beck, Stewart, Gadberry, Haque and Biermacher, 2016). The level of nutrition also has an influence on the weight of the calves at weaning, which is a result of the milk production of the cows (Lemaster, Taylor, Ricks, \& Long, 2017). Under conditions of feed restrictions or insufficient intake to meet the requirements of the cow during lactation, nutritional anoestrus occurs (Funston, Larson, \& Vonnahme, 2010), caused by the increased energy requirement of the lactating cow (National Research Council [NRC], 2016).

The costs of calf production are high, and in order to achieve better economic results, adjustments in production systems are necessary with the aim of achieving greater production efficiency. Gonçalves et al. (2017), evaluating the costs of calf production in a breeding system where the calves are sold at weaning, found negative profitability in production systems with a $60 \%$ birth rate, the balance point being a birth rate of $85 \%$, at which point, providing errors are minimised, the breeding system becomes sustainable.
When feeding consists basically of native pasture, it becomes difficult to achieve high productivity. In addition to the above factors, adjusting available nutrition to the animal biotype being bred should be taken into consideration (Farias et al., 2018a,b). Choosing the right animal for the environment is essential for increasing the productivity of breeding herds, and the animal should adjust to the environmental conditions and produce in a sustainable way. The aim of this study was to evaluate different body sizes in beef cows of maternal ability and the productive efficiency of breeding herds in natural pasture.

\section{Material and Methods}

\section{Study location}

The experiment was carried out at the Beef Livestock Laboratory of the Department of Animal Science at the Federal University of Santa Maria, located in the Central Depression of Rio Grande do Sul, at $29^{\circ} 43^{\prime} \mathrm{S}$ and $53^{\circ} 42^{\prime} \mathrm{W}$ at an altitude of $95 \mathrm{~m}$. All procedures were approved by the Institutional Committee on Animal Use (CEEA $n^{\circ}$ 8250-2015).

\section{Animals, treatment, diets and management}

Eighty pairs of cows, aged from 3 to 7 years were used, with calves resulting from the continuous alternating crossing of the Charolais and Nellore breeds; these were grouped into three weight classes, which were formed based on the standard deviation of the mean body weight of the 
batch of cows at calving. The following groups were formed by adding or subtracting 0.5 standard deviations $(53.99 \mathrm{~kg})$ from the overall mean weight of the cows, of $386.59 \mathrm{~kg}$ : light (cows with a mean weight of $332.6 \mathrm{~kg}$, ranging from 282 to $361 \mathrm{~kg}$ ), moderate (cows with a mean weight of $385.3 \mathrm{~kg}$, ranging from 363 to $420 \mathrm{~kg}$ ) and heavy (cows with a mean weight of $444.7 \mathrm{~kg}$, ranging from 423 to 525 $\mathrm{kg}$ ). The treatments included a total of 26,28 and 26 cows for the light, moderate and heavy groups respectively.

Of the 80 cows, 40 were pure or crossbred with a predominance of Charolais blood (C, 11/16C $5 / 16 \mathrm{~N}$ and $21 / 32 \mathrm{C} 11 / 32 \mathrm{~N}$ ) and 40 were pure or crossbred cows with a predominance of Nellore blood (N, 11/16N 5/16C and 21/32N 11/32C). To minimise the effect of the different genetic groups and the different ages of the cows, an equivalent distribution by age and genetic group was made in the three body-size groups.

The cows were kept as a single batch on native pasture, at a mean stocking rates density of 0.6 $\mathrm{AU} / \mathrm{hectare}(\mathrm{AU}=$ animal unit $=450 \mathrm{~kg})$. Grasses and legumes make up a large part of the botanical composition of natural pastures, with the grasses mainly represented by Paspalum notatum along the tops and slopes of hills, and stoloniferous grasses, such as carpetgrass (Axonopus fissifolium), in wet lowlands. Included in the legumes are some clovers, family Desmodium being prominent. Where the animal load is greater than the carrying capacity, there is a reduction in this plant community, with an increase in the number of compounds, such as: Solivapterosperm, Conyzabanariensisand Senecio brasiliensis (Andrade et al., 2015). Recently, Eragrotis Plana Nees has become more widespread (Andrade et al., 2015).

The cows, both pre- and postpartum, received a supplement of calcium salts in the proportion of 60 and $100 \mathrm{~g} \mathrm{cow}^{-1}$ day $^{-1}$ fatty-acid calcium salts (Megalac ${ }^{\circledR}-\mathrm{E}$, Church \& Dwight Company), following the recommendations for the product, but adapted for the weight of the cows under study. During the breeding period, a rotation system with two paddocks was used to separate the cows for mating based on breed to maintain continuous alternating crossbreeding.

After weaning, the calves were all submitted to the same feeding management. Early weaning of the calves took place on average 63 days postpartum. The calves were permanently separated from the cows and kept in a pen for 10 days to reduce the stress of being separated from their mothers, with access to good quality water and supplemented with feed containing $22 \%$ crude protein and $75 \%$ total digestible nutrients. Afterward they were then maintained on a pasture of Tifton grass (Cynodon spp.) supplemented with concentrate equivalent to $1 \%$ of live weight, containing $20 \%$ crude protein (maize, soybean meal and wheat meal). From five to 12 months of age, they bran on native pasture without supplement.

The breeding period was 90 days; the method of breeding was natural mating, with bulls previously tested for their service capacity. Four previously tested bulls were used, two Charolais and two Nellore. Sixty days after the end of the breeding period a diagnosis of pregnancy was carried out by manual rectal examination and the use of ultrasound. Throughout the experimental period the cows received mineral supplement in troughs, formulated to be consistent of the category based on the stage of the production cycle. The control of endo- and ectoparasites was carried out strategically using full spectrum products, with the vaccinations following the timetable of the Brazilian Ministry of Agriculture, Fisheries and Supply.

\section{Measurements and calculations of indicators}

The cows and calves were weighed during the first 24 hours after calving, at weaning (63 days postpartum), at the end of the breeding period and during the diagnosis of pregnancy. Weighing was 
also carried out every 21 days to control and adjust the stocking density. Daily variations in weight were determined from the difference in body weight between weighing divided by the number of days between weighings.

The production efficiency of the cows at calving and weaning was calculated by dividing the weight of the calves at weaning by the body weight of cows at calving and weaning respectively, and multiplying by 100 , with the result in kilograms of calf for every 100 kilograms of cow in the herd (M. F. Silveira et al., 2019b). The calf production index was determined by multiplying the pregnancy rate of the cows by the weight of the calves at weaning, expressed in kilograms of calf weaned per cow in the herd (M. F. Silveira et al., 2019b).

The area required for production by the cowcalf pair was determined based on the body weights of the two categories and the animal load used to maintain the herd. The overall productive efficiency was evaluated up to 210 days postpartum. For this calculation, the total production of the cow-calf pair in kilograms was divided by the area required for their maintenance.

\section{Evaluation of milk production and quality}

The milk production efficiency of the cows was determined in kilograms of milk for the production of one kilogram of calf (kilograms of milk/kilogram of calf), and as a percentage of the probable milk consumption of the calf for its gain in body weight (kilogram of calf/kilogram of milk*100).

Milk samples were collected 21, 42 and 63 days postpartum. Milk production was measured directly by manual milking. The cows were separated from their calves in the morning (one day before collection) and kept in a closed paddock. At $18 \mathrm{~h} 00$ the cows were again placed with the calves, where they remained for 30 minutes, to completely empty the udder. The calves were again separated from their mothers, remaining in the pen until the following morning. Milking the cows began approximately $12 \mathrm{~h} 00$ hours after the last calf feeding. For this, the cows were constrained by the neck and $3 \mathrm{~m} \mathrm{~L}^{-1}$ oxytocin were applied intramuscularly to facilitate descent of the milk. Milking was performed on two milk let down of the udder, one frontal and one rear. The resulting production was multiplied by two to obtain the total milk production of the udder, and later adjusted for $24 \mathrm{~h} 00$ hours (M. F. Silveira et al., $2019 b)$. Total milk production was estimated from the sum of the measurements from days 21,42 , and 63 postpartum, individually multiplied by 21 .

Individual $100 \mathrm{~m} \mathrm{~L}^{-1}$ samples were collected from the milk taken from the cows and sent to the Laboratory of the Dairy Herd Analysis Service (SARLE) at the Food Research Centre (CEPA) of the University of Passo Fundo (UPF) to determine the physical composition of the milk, including the levels of fat, lactose, total dry extract, defatted dry extract and crude protein. Intermediate evaluations were removed from the results as there was no difference between weight groups for the parameters under evaluation, and only the mean production of the milk and its components were considered.

\section{Statistical analysis}

The experimental design was completely randomised. The collected data were subjected to analysis of variance, including in the statistical model the fixed effect of cow size, with age and genetic group used as covariates. The data were analysed using the SAS v 6.08 statistical software (Statistical Analysis System [SAS], 2001), adopting $5 \%$ as the maximum significance level by t-test. The pregnancy rate was analysed using the Chi-square test at $5 \%$ significance. 


\section{Results}

The weight of the cows differed $(\mathrm{P}<0.05)$ for body size in each of the evaluations, from calving to the diagnosis of pregnancy, keeping the difference between weight groups (Table 1).

Calves born from light cows were less heavy at birth compared to those from cows classified as moderate or heavy (Table 1). At weaning, calves from heavy cows were superior $(\mathrm{P}<0.05)$ in weight $(88.6 \mathrm{~kg})$ compared to calves from moderate $(82.1$ $\mathrm{kg})$ and light $(72.2 \mathrm{~kg})$ cows, which did not differ from each other $(\mathrm{P}>0.05)$.

After weaning, the weight of the calves differed $(\mathrm{P}<0.05)$ from 150 to 210 days of age, with calves born from heavy cows being heavier compared to those from moderate and light cows. At 365 days, the calves of heavy cows $(185.1 \mathrm{~kg})$ were superior $(\mathrm{P}<0.05)$ to the calves of light cows, but did not differ $(\mathrm{P}>0.05)$ from those of moderate cows $(178.8$ $\mathrm{kg}$ ), which in turn did not differ from the calves of light cows $(168.5 \mathrm{~kg})$.

Table 1

Mean values and standard errors for weight characteristics with variations during lactation in beef cows and their calves, classified for different body types

\begin{tabular}{lccc}
\hline \multicolumn{1}{c}{ Characteristic } & Light & Moderate & Heavy \\
\hline Weight, $k g$ & & & \\
Cows at calving & $332.6 \pm 4.7^{\mathrm{c}}$ & $385.3 \pm 4.0^{\mathrm{b}}$ & $444.7^{\mathrm{b}} \pm 4.9^{\mathrm{a}}$ \\
Cows at weaning & $337.0 \pm 6.5^{\mathrm{c}}$ & $390.5 \pm 5.6^{\mathrm{b}}$ & $447.6 \pm 6.9^{\mathrm{a}}$ \\
End of breeding & $358.8 \pm 6.1^{\mathrm{c}}$ & $410.8 \pm 5.3^{\mathrm{b}}$ & $470.0 \pm 6.5^{\mathrm{a}}$ \\
Diagnosis of pregnancy & $397.0 \pm 6.5^{\mathrm{c}}$ & $450.4 \pm 5.6^{\mathrm{b}}$ & $512.5 \pm 6.9^{\mathrm{a}}$ \\
Calves at birth & $32.3 \pm 0.9^{\mathrm{b}}$ & $35.4 \pm 0.8^{\mathrm{a}}$ & $35.8 \pm 1.0^{\mathrm{a}}$ \\
Calves at weaning (63 days) & $72.2 \pm 1.8^{\mathrm{b}}$ & $82.1 \pm 1.5^{\mathrm{b}}$ & $88.6 \pm 1.9^{\mathrm{a}}$ \\
Calves at 150 days & $135.4 \pm 4.3^{\mathrm{b}}$ & $147.6 \pm 3.7^{\mathrm{a}}$ & $149.3 \pm 4.6^{\mathrm{a}}$ \\
Calves at 210 days & $152.1 \pm 5.0^{\mathrm{b}}$ & $167.6 \pm 4.3^{\mathrm{a}}$ & $170.7 \pm 5.3^{\mathrm{a}}$ \\
Calves at 365 days & $168.5 \pm 6.0^{\mathrm{b}}$ & $178.8 \pm 5.2^{\mathrm{ab}}$ & $185.1 \pm 6.3^{\mathrm{a}}$ \\
Mean variation in body weight, $k g d a y^{-1}$ & & & \\
Cow from calving to weaning & $0.06 \pm 0.05^{\mathrm{a}}$ & $0.08 \pm 0.04^{\mathrm{a}}$ & $0.04 \pm 0.05^{\mathrm{a}}$ \\
Calf from birth to weaning & $0.74 \pm 0.02^{\mathrm{b}}$ & $0.74 \pm 0.02^{\mathrm{b}}$ & $0.83 \pm 0.02^{\mathrm{a}}$ \\
\hline
\end{tabular}

$\mathrm{a}, \mathrm{b}, \mathrm{c}$ on the same line differ $(\mathrm{P}<0.05)$ by t-test.

Up to weaning, the average daily gain in body weight in calves born to light and moderate cows was lower $(\mathrm{P}<0.05)$ than in calves born to heavy cows.

The pregnancy rate of the cows was similar $(\mathrm{P}>0.05)$ for the three cow weight groups, with mean values of $84.6,85.7$ and $88.4 \%$ for light, moderate and heavy cows respectively (Table 2 ).
Light cows were more efficient at calving and weaning at 63 days, producing more kilograms of calf for every 100 kilograms of cow in the herd, compared to the moderate and heavy cows.

Associating the weight of the calves at weaning with pregnancy, the heavy cows produced 78.5 kilograms of calf per cow in the herd, which was superior $(\mathrm{P}<0.05)$ to the 70.4 and 67.1 kilograms of calf of the moderate and light cows respectively. 
Table 2

Mean values and standard errors for production characteristics in cattle herds of different body types

\begin{tabular}{lccc}
\hline Characteristic & Light & Moderate & Heavy \\
\hline Pregnancy, \%\# & 84.6 & 85.7 & 88.4 \\
Efficiency of the cow at calving ${ }^{1}, \mathrm{~kg}$ & $23.7 \pm 0.5^{\mathrm{a}}$ & $21.3 \pm 0.4^{\mathrm{b}}$ & $19.9 \pm 0.5^{\mathrm{b}}$ \\
Efficiency of the cow at weaning $^{2}, \mathrm{~kg}$ & $23.4 \pm 0.6^{\mathrm{a}}$ & $21.1 \pm 0.5^{\mathrm{b}}$ & $19.9 \pm 0.6^{\mathrm{b}}$ \\
Calf production index ${ }^{3}, \mathrm{~kg}$ & $67.1 \pm 1.5^{\mathrm{b}}$ & $70.4 \pm 1.3^{\mathrm{b}}$ & $78.5 \pm 1.6^{\mathrm{a}}$ \\
Production area up to 210 days $^{4}, \mathrm{ha}$ & $1.35 \pm 0.03^{\mathrm{c}}$ & $1.52 \pm 0.02^{\mathrm{b}}$ & $1.69 \pm 0.03^{\mathrm{a}}$ \\
Production of the cow-calf pair, $\mathrm{kg}$ & $184.2 \pm 6.3^{\mathrm{a}}$ & $197.3 \pm 5.5^{\mathrm{a}}$ & $202.7 \pm 6.7^{\mathrm{a}}$ \\
\hline Overall productive efficiency $^{5}, \mathrm{~kg} / \mathrm{ha}$ & $106.8 \pm 2.0^{\mathrm{a}}$ & $100.7 \pm 1.7^{\mathrm{a}}$ & $93.1 \pm 2.1^{\mathrm{b}}$ \\
\hline
\end{tabular}

$\mathrm{a}, \mathrm{b}, \mathrm{c}$ on the same line differ $(\mathrm{P}<0.05)$ by t-test; $\#$ - Chi-square test;

1 - Calf weight at 63 days/cow weight at calving*100;

2 - Calf weight at 63 days/cow weight at weaning at 63 days*100;

3 - Calf weight at weaning at 63 days*cow pregnancy/100;

4 - Weight of the cow and calf/405 (0.9 AU);

5 - Production of the cow-calf pair in kilograms/area required for production.

The area of pasture necessary to maintain the cow-calf pair, from calving up to 210 days, increased with the increase in animal biotype. Light cows required 1.35 ha, which is less $(\mathrm{P}<0.05)$ than the 1.52 hectares needed for moderate cows, and these were both less than the 1.69 hectares required to maintain the heavy cow-calf pair. However, kilogram production was similar between the three animal biotypes $(\mathrm{P}>0.05)$. Combining these two factors to determine the overall production efficiency, lower values per hectare for kilogram production in the cow-calf pair were found in the group of heavy cows than in the moderate and light cows, with no difference between the last two groups $(\mathrm{P}>0.05)$.

Mean daily milk production was similar $(\mathrm{P}>0.05)$ for the three body sizes, with values of 5.64, 6.18 and 6.21 litres per day for the light, moderate and heavy cows respectively (Table 3 ).

Table 3

Mean values and standard errors for milk production and milk quality in cattle herds of different body types

\begin{tabular}{lccc}
\hline Characteristic & Light & Moderate & Heavy \\
\hline Mean milk production, litres & $5.64 \pm 0.54^{\mathrm{a}}$ & $6.18 \pm 0.30^{\mathrm{a}}$ & $6.21 \pm 0.45^{\mathrm{a}}$ \\
Milk efficiency, \% & $0.13 \pm 0.01^{\mathrm{a}}$ & $0.12 \pm 0.00^{\mathrm{a}}$ & $0.14 \pm 0.00^{\mathrm{a}}$ \\
Milk efficiency, litres kg ${ }^{-1}$ & $7.92 \pm 0.64^{\mathrm{a}}$ & $8.28 \pm 0.36^{\mathrm{a}}$ & $7.32 \pm 0.53^{\mathrm{a}}$ \\
Mean fat & $3.70 \pm 0.27^{\mathrm{a}}$ & $3.47 \pm 0.15^{\mathrm{ab}}$ & $2.79 \pm 0.22^{\mathrm{b}}$ \\
Mean protein & $3.13 \pm 0.14^{\mathrm{a}}$ & $2.97 \pm 0.07^{\mathrm{a}}$ & $2.84 \pm 0.11^{\mathrm{a}}$ \\
Mean lactose & $4.68 \pm 0.09^{\mathrm{a}}$ & $4.65 \pm 0.05^{\mathrm{a}}$ & $4.68 \pm 0.07^{\mathrm{a}}$ \\
Mean total dry extract & $11.98 \pm 0.35^{\mathrm{a}}$ & $11.69 \pm 0.19^{\mathrm{a}}$ & $11.24 \pm 0.29^{\mathrm{a}}$ \\
Total defatted dry extract & $8.27 \pm 0.19^{\mathrm{a}}$ & $8.24 \pm 0.11^{\mathrm{a}}$ & $8.55 \pm 0.16^{\mathrm{a}}$ \\
\hline
\end{tabular}

$\mathrm{a}, \mathrm{b}, \mathrm{c}$ on the same line differ $(\mathrm{P}<0.05)$ by t-test. 
The composition and quality of the milk were similar between the cow sizes for protein, lactose, dry extract and defatted dry extract. In the production of milk fat, light cows were superior to heavy cows, and did not differ from moderate cows, which in turn did not differ from heavy cows.

\section{Discussion}

The weight at calving and at the beginning and end of the reproductive period are important, as they show a positive correlation with higher rates of pregnancy in the cows (Bohnert etal., 2013; Gutiérrez et al., 2014). When feeding conditions are not ideal, milk production and the consequent development of the calf may be impaired (Scasta, Henderson, \& Smith, 2015); but especially reproduction, as this is not a priority in nutrient partitioning (Burns, Fordyce and Holroyd, 2010), and shows responses which are inconsistent with productive livestock. Lactation is the most challenging period for the cows. Nutritional demand increases up to the peak of milk production around the eighth week of lactation, showing a gradual increase (NRC, 2016). Under conditions of quantitative and qualitative limitations on grazing, these demands are generally not completely met, with the cows using their body reserves (Bohnert et al., 2013) to maintain production, affecting their performance as a result. While the cows are still growing, this may be aggravated by the greater body size of the cows and, consequently, their greater nutritional demand (Farias et al., 2018a), which can influence reproduction (Farias et al., 2018b; Bitencourt et al., 2020 ), or by the demands of growth competing with and affecting the reproductive performance and productivity of the herds, even when maintained under good nutritional conditions (Castilho et al., 2018).

Greater body weight in the calves at birth is a result of the greater body weight of the cows, which is associated with greater morphometric measurements and, consequently, a larger internal space for maintenance of the vital organs and the reproductive system in the abdominal cavity of heavy cows (Mota, Mariz, Ribeiro, Silva, \& Lima, 2015 ), in addition to greater placental nutrition of the foetus, a phase that is crucial to its development (Funston et al., 2010). This can be seen in cows with a predominance of the Nellore breed, where those of larger body size produce heavier calves at birth, probably due to the limited space for embryonic and foetal development in the abdominal cavity of smaller cows (Farias et al., 2018a).

After weaning, calves born to heavy and moderate cows continue to be larger and to show greater development than calves born to smaller cows; This is probably due to their greater size and adult weight, part of which is genetically inherited from their larger mothers. This determines greater development and greater body weight at the various stages of their lives, where, during the post-weaning period, development is dependent on individual potential and on the influence exerted by the environment and management (D. D. Silveira et al., 2019a). When feeding via maternal milk is lost, calves basically need to obtain their food from the available pasture, and as such, their performance is a reflection of the quality of the food and their ability to transform it into weight gain (M. F. Silveira et al., 2019b). When feeding conditions are adequate, large animals suffer no restrictions on feeding (Beck et al., 2016). However, when feeding is not ideal, animal development and performance are compromised (Silva et al., 2015). In the present study, the feeding conditions up to 365 days of age met the demands of the calves, with animals born to larger cows reaching a greater body weight.

Generally, smaller cows show greater efficiency at weaning (Farias et al., 2018b). However, the selection of moderate-sized cows is more advantageous, as it generates lower maintenance costs than selecting larger cows to produce heavier calves with greater average daily gains (Silva et al., 2015). In addition, there are other advantages, which are related to the capacity for keeping more cows, 
fixed costs distributed over more animals, higher returns on operating costs, and lower individual costs for animal maintenance (Doye \& Lalman, 2011).

The results of the present study demonstrate that the ratio of calf weight in kilograms produced for each hundred kilograms of cow in the herd increases with a reduction in cow size. According to Silva et al. (2015), in their study using 706 weight observations of the cow-calf pair at weaning, comparing six groups of cows of different weights, they obtained a progressive improvement in the ratio of calf weight at weaning to kilogram of cow weight at weaning, for reductions in cow weight. This relationship may eventually influence the breeding system, considering that most producers choose the heaviest cows, which are then responsible for the biological and productive results of the herds (Beck, Gadberry, Gunter, Kegley and Jennings, 2017).

The calf production index is an important indicator, as it combines the pregnancy rate with the calf weight at weaning, reflecting the biological efficiency of the cows. The level of nutrition and the use of early weaning technology (Tao et al., 2018) favoured the reproductive performance of the cows, achieving mean values greater than $80 \%$ pregnancy, which is consistent with advanced beef farming. Early weaning favours the reproductive parts of the cow, which are inhibited by the presence of the calf and by milk production, the latter being very costly for the animal (M. F. Silveira et al., 2019b). After weaning, all the nutrients that were previously directed to milk production are used for weight recovery and the body condition score; for the nervous system, this indicates an improvement in the nutritional level, activating the reproductive parts previously inhibited due to the nutritional deficiency (Tao et al., 2018; M. F. Silveira et al., 2019b).

The weight of the calves at weaning together with the pregnancy of the cows shows that even the heavy cows, which consume more food and are therefore more costly to the production system, produce more kilograms of calf, since efficiency is related to the environment, to the animal and to the interaction between the two (Mulliniks et al., 2015).

The greater efficiency of light cows, expressed in kilograms of calf at weaning per kilogram of cow at calving and at weaning, is due to the lower demand for crude protein and total digestible nutrients required for maintenance and production in these animals (NRC, 2016). As such, smaller cows suffer less from environmental and nutritional changes in the production system and are able to maintain more-stable production compared to animals of a larger biotype (Mulliniks et al., 2012).

Farias et al. (2018b), evaluating production by area, found that smaller cows produce more kilograms of calf per surface area, even having less weight at weaning. These authors point out that for each breed and environment, there will be an ideal animal type. Heavier cows produce calves that are heavier at birth and at weaning; however, production per area may be lower, as heavy cows require a larger available area (Castilho et al., 2018; Farias et al., 2018a).

The similarity in milk production between the weight groups shows that body size does not influence milk production. The literature is contradictory concerning body size and milk production in cows. Non-significant correlations were found between the size of the cow and milk production, showing that increased milk production is little influenced by the characteristics that confer greater body size (Campos, Cobuci, Kern, Costa and Mcmanus, 2015). This underlines the fact that cows from lineages of different sizes showed differing variations in their physical characteristics, but similarities in milk production, with medium-sized cows being more efficient (Hansen, Cole, Marx, \& Seykora, 2000). In the present study, the lack of any difference in milk production is partly due to the short lactation period of the calves, a result of early weaning at 63 days. 
Calf performance shows a positive correlation with greater milk consumption; however, it is not only the quantity of milk that is important, but also the quality (Lemaster et al., 2017). The conditions of the present study afforded similar quality to the milk produced by the cows, except for the fat content, where the smaller cows produced the greatest levels of this component. The greater percentage of fat at the start of lactation results in many variations in the postpartum negative energy balance and, consequently, in the contribution of body reserves to the synthesis of milk fat at this stage of lactation (Samková, Špička, Pešek, Pelikánová, \& Hanuš, 2012). In this study, cow size was probably the determinant factor in milk-fat production. The heavy and moderate cows were unable to obtain from the natural pasture the nutrients necessary to produce a fat content similar to that of the light cows, whose nutritional demand is less and who are able to meet their demands more easily, thereby becoming more efficient (Lemes, Pimentel, Vaz, Farias, \& Brauner, 2017).

\section{Conclusions}

The body size of the cow determines the weight of the calf, where, compared to light cows, heavier cows produce heavier calves up to 365 days of age.

The reproductive performance of the cows is not affected by the increase in cow size when the nutritional conditions are not limiting.

The production of kilograms of calf for every 100 kilograms of cow at calving and weaning is higher in smaller cows.

The production of kilograms of calf adjusted for the pregnancy rate of the cows is higher in large cows. However, large cows require a larger area for maintenance, and their production efficiency in kilograms of calf per area is lower.

\section{Compliance with ethical standards conflict of interest}

The authors declare that they have no conflict of interest.

\section{Statement on animal rights}

All procedures were approved by the Institutional Committee on Animal Use (CEEA no 8250-2015).

\section{Acknowledgements}

This work was supported by the Coordenação de Aperfeiçoamento de Pessoal de Nível Superior - Brasil (CAPES) for the partial financing by Finance Code 001. Support by Conselho Nacional de Desenvolvimento Científico e Tecnológico (CNPq) grant 303246/2015-4.

\section{References}

Andrade, B. O., Koch, C., Boldrini, I. I., Vélez-Martin, E., Hasenack, H., Hermann, J. M.,... Overbeck, G. E. (2015). Grassland degradation and restoration: a conceptual framework of stages and thresholds illustrated by southern Brazilian grasslands. Natureza \& Conservação, 13(1), 95-104. doi: 10.1016/j. ncon.2015.08.002

Beck, P. A., Gadberry, M. S., Gunter, S. A., Kegley, E. B., \& Jennings, J. A. (2017). Invited review: matching forage systems with cow size and environment for sustainable cow-calf production in the southern region of the United States. Applied Animal Science, 33(3), 289-296. doi: 10.15232/pas.2016-01557

Beck, P. A., Stewart, C. B., Gadberry, M. S., Haque, M., \& Biermacher, J. (2016). Effect of mature body weight and stocking rate on cow and calf performance, cow herd efficiency, and economics in the southeastern United States. Journal of Animal Science, 94(4), 1689-1702. doi: 10.2527/jas.2015-0049

Bitencourt, M. F., Cerdótes, L., Restle, J., Costa, P. T., Fernandes, T. A., Ferreira, O. G. L., \& Vaz, R. Z. (2020). Age and calving time affect production efficiency of beef cows and their calves. Anais da Academia Brasileira de Ciências, 92(Spupl. 1), e20181058. doi: 10.1590/0001-37652020181058 
Bohnert, D. W., Stalker, L. A., Mills, R. R., Nyman, A., Falck, S. J., \& Cooke, R. F. (2013). Late gestation supplementation of beef cows differing in body condition score: Effects on cow and calf performance. Journal of Animal Science, 91(11), 5485-5491. doi: 10.2527/jas.2013-6301

Burns, B. M., Fordyce, G., \& Holroyd, R. G. (2010). A review of factors that impact on the capacity of beef cattle females to conceive, maintain a pregnancy and wean a calf-Implications for reproductive efficiency in northern Australia. Animal Reproduction Science, 122(1), 1-22. doi: 10.1016/j.anireprosci. 2010.04.010

Campos, R. V., Cobuci, J. A., Kern, E. L., Costa, C. N., \& Mcmanus, C. M. (2015). Genetic parameters for linear type traits and milk, fat, and protein production in Holstein cows in Brazil. Asian-Australasian Journal of Animal Sciences, 28(4), 476-484. doi: 10.5713/ajas.14.0288

Castilho, E. M., Vaz, R. Z., Fernandes, T. A., Farias, G. D., Boligon, A. A., Conceição, V. G. D., \& Brum, O. B. (2018). Precocidade de parto na estação de parição sobre a eficiência produtiva de vacas primíparas aos 24 meses de idade. Ciência Animal Brasileira, 19(9), 1/46667-9. doi: 10.1590/1809-689 1v19e-46667

Doye, D., \& Lalman, D. L. (2011). Moderate versus big cows: do big cows carry their weight on the ranch? Proceeding of Southern Agricultural Economics Association Annual Meeting, Corpus Christi, Texas, Estados Unidos da América. doi: 10.22004/ ag.econ. 98748

Farias, G. D., Cerdótes, L., Restle, J., Pascoal, L. L., Costa, P. T., Ferreira, O. G. L., \& Vaz, R. Z. (2018a). Body size and its effects on productive efficiency of cows with predominant Nellore genetic composition. Acta Scientiarium Animal Science, 40(1), e42532. doi: 10.4025/actascianimsci.v40i1.425 32

Farias, G. D., Cerdótes, L., Vaz, R. Z., Restle, J., Bitencourt, M. F., Alves, D. C., F ${ }^{o}$, \& Brondani, I. L. (2018b). Biological efficiency of Charolais beef cows of different body sizes. Semina: Ciências Agrárias, 39(4), 1737-1748. doi: 10.5433/1679-0359.2018v39 n4p 1737

Funston, R. N., Larson, D. M., \& Vonnahme, K. A. (2010). Effects of maternal nutrition on conceptus growth and offspring performance: implications for beef cattle production. Journal of Animal Science, 88(13 Suppl.), E205-215. doi: 10.2527/jas.20092351

Gonçalves, G. V. B., Vaz, R. Z., Vaz, F. N., Mendonça, F. S., Fontoura, J. A. S., Jr., \& Castilho, E. M. (2017).
Análise de custos, receitas e ponto de equilíbrio dos sistemas de produção dos sistemas de produção de bezerros no Rio Grande do Sul. Ciência Animal Brasileira, 18(1), e46329. doi: 10.1590/10 89$6891 v 18 \mathrm{e}-46329$

Gutiérrez, V., Espasadín, A. C., Machado, P., Bielli, A., Genovese, P., \& Carriquiry, M. (2014). Effects of calf early nutrition on muscle fiber characteristics and gene expression. Livestock Science, 167(9), 4018-4016. doi: 10.1016/j.livsci.2014.07.010

Hansen, L. B., Cole, J. B., Marx, G. D., \& Seykora, A. J. (2000). Consequences of Selection for milk yield from a geneticist's viewpoint. Journal of Dairy Science, 83(5), 1145-1150. doi: 10.3168/jds.S00220302 (00)74980-0

Lemaster, C. T., Taylor, R. K., Ricks, R. E., \& Long, N. M. (2017). The effects of late gestation maternal nutrient restriction whit or without protein supplementation on endocrine regulation of newborn and postnatal beef calves. Theriogenology, 87(1), 64-71. doi: 10.1016/j.theriogenology.2016.08.004

Lemes, J. S., Pimentel, M. A., Vaz, R. Z., Farias, L. B., \& Brauner, C. C. (2017). Performance efficiency of pasture-raised primiparous beef cows of three different biotypes and two milk production levels. Acta Scientiae Veterinariae, 45(1461), 1-8. Recovered from https://seer.ufrgs.br/ActaScientiaeVeterinariae/ article/view/80 210/47050

Mota, L. F. M., Mariz, T. M. A., Ribeiro, J. S., Silva, M. E. F. da, \& Lima, D. M., Jr. (2015). Divergências morfométricas em bovinos Nelore em crescimento classificados para diferentes classes de frame size. Revista Caatinga, 28(2), 117-125. Recovered from https://periodicos.ufersa.edu.br/index.php/caatinga/ article/view/3666/pdf_253

Mulliniks, J. T., Cox, S. H., Kemp, M. E., Endecott, R. L., Waterman, R. C., Vanleeuwen, D. M., \& Petersen, M. K. (2012). Relationship between body condition score at calving and reproductive performance in young postpartum cows grazing native range. Journal of Animal Science, 90(8), 2811-2817. doi: 10.2527/jas.2011-4189

Mulliniks, J. T., Rius, A. G., Edwards, M. A., Edwards, S. R., Hobbs, J. D., \& Nave, R. L. G. (2015). Forages and pastures symposium: improving efficiency of production in pasture- and range-based beef and dairy systems. Journal of Animal Science, 93(12), 2609-2615. doi: 10.2527/jas2014-8595

National Research Council (2016). Nutrient requirements of beef cattle (8nd ed.). Washington: National Academy Press. 
Samková, E., Špička, J., Pešek, M., Pelikánová, T., \& Hanuš, O. (2012). Animal factors affecting fatty acid composition of cow milk fat: a review. South African Journal of Animal Science, 42(2), 83-100. doi: 10. 4314/sajas.v42i2.1

Scasta, J. D., Henderson, L., \& Smith, T. (2015). Drought effect on weaning weight and efficiency relative to cow size in semiarid rangeland. Journal Animal Science, 93(12), 5829-5839. doi: 10.2527/jas.20159172

Silva, R. M., Souza, J. C., Fernandes, H. J., Abreu, U. G. P., Ferraz, P. B., Fo., \& Rosa, A. N. (2015). Eficiência produtiva ao desmame de vacas Nelore criadas no Pantanal. Arquivo Brasileiro de Medicina Veterinária e Zootecnia, 67(4), 1105-1110. doi: 10.1590/16784162-6909

Silveira, D. D., Vargas, L., Pereira, R. J., Campos, G. S., Vaz, R. Z., Lôbo, R. B., \& Boligon, A. A. (2019a). Quantitative study of genetic gain for growth, carcass, and morphological traits of Nelore cattle. Canadian Journal of Animal Science, 99(2), 296306. doi: 10.1139/cjas-2018-0078
Silveira, M. F., Restle, J., Brondani, I. L., Machado, D. S., Pacheco, R. F., Argenta, F. M., \& Hoffmann, F. (2019b). Effect of age and genetic group on the development of calves weaned at 63 days until one year of age. Semina: Ciências Agrárias, 40(4), 16311638. doi: 10.5433/1679-0359.2019v40n4p1631

Statistical Analysis System. Stat user's guide. Version 9. Carry: SAS Institute, 2001. CDROM.

Tao, H., Guo, F., Tu, Y., Si, B.-W., Xing, Y.-C., Huang, D.-J \& Diao, Q.-Y. (2018). Effect of weaning age on growth performance, feed efficiency, nutrient digestibility and blood-biochemical parameters in Droughtmaster crossbred beef calves. Asian Australasians Journal of Animal Science, 31(6), 864-872. doi: 10.5713/ajas.17.0539 
